\title{
COMPARISON OF GROUND TECHNIQUES USED TO ESTIMATE CLOUD COVER IN FLORIANÓPOLIS, SOUTHERN BRAZIL
}

\author{
Mariza Pereira de Souza Echer ${ }^{1}$, Fernando Ramos Martins ${ }^{2}$, Roberto Tadeu de Araujo ${ }^{3}$, \\ Marcela de Ávila Villaron ${ }^{4}$, Marcos Luiz de Andrade Pinto ${ }^{5}$ and Cleber Souza Corrêa ${ }^{5}$
}

\begin{abstract}
Cloud cover is a key feature in Earth images acquired from space. Cloud cover data play a significant role in the weather forecast and climate knowledge, as well as in several human activities. Several studies have been conducted to establish a methodology and experimental setup in order to acquire reliable cloud cover data from remote sense observations performed on the surface. This research aimed at comparing ground data acquired by different systems for the same atmospheric scenario regarding cloud cover. Solar radiation data and sky images acquired at SONDA station located in Florianópolis, in 2002, were used to evaluate cloud cover. Also, cloud cover data collected at the international airport meteorological station distant 7,700 $\mathrm{m}$ from the SONDA station were used. This work compares these two sets of data acquired for sky scenarios with only one type of cloud. The results show good agreement in clear and completely overcast sky conditions. Future studies using longer time series will be developed in order to evaluate the influence of seasonal variability and atmospheric scenarios with several cloud types (low, medium and high clouds).
\end{abstract}

Keywords: cloud cover, radiative transmittance, remote sensing, SONDA network, cloud cover data.

RESUMO. A característica principal da Terra quando vista do espaço é sua cobertura de nuvens. A nebulosidade desempenha um papel primordial em estudos relacionados à previsão do tempo e do clima, bem como em diferentes atividades humanas. Diversos estudos vêm sendo realizados com o intuito de desenvolver metodologias adequadas para o monitoramento em superfície da cobertura de nuvens. Este trabalho teve por objetivo principal verificar se plataformas distintas apresentam reprodutibilidade e sensibilidade na aquisição de dados de um mesmo cenário atmosférico no que se refere à nebulosidade. Foram utilizadas medidas de radiação solar e dados de cobertura de nuvens coletados na superfície com um sistema automático de monitoramento utilizando uma câmera do tipo al/-Sky realizadas na estação SONDA localizada em Florianópolis em 2002. A terceira base de dados utilizada refere-se aos valores registrados por inspeção visual no Aeroporto Internacional de Florianópolis, distanciado em 7,700 m da estação SONDA. Apenas casos de nebulosidade por um único tipo de nuvens foram analisados neste estudo. Os resultados mostraram boa concordância em condições de céu claro e completamente nublado. Os casos estudados neste trabalho sugerem que sejam usadas séries temporais mais longas para avaliar a influência da sazonalidade dos diversos tipos de cobertura de nuvens (baixas, médias e altas) e sua distribuição espacial no céu.

Palavras-chave: cobertura de nuvens, transmitância radiativa, sensoriamento remoto da atmosfera, projeto SONDA, observação de nuvens.

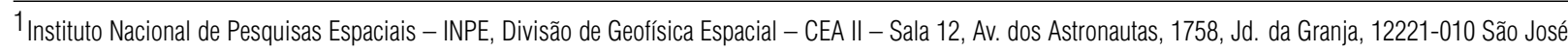
dos Campos, SP, Brazil. Phone: +55(12) 3208-7809; Fax: +55(12) 3941-1875 - E-mail : mariza.echer@inpe.br

2 Instituto Nacional de Pesquisas Espaciais - INPE, Centro de Ciência do Sistema Terrestre - CCST, Av. dos Astronautas, 1758, Jd. da Granja, 12221-010 São José dos Campos, SP, Brazil. Phone: +55(12) 3208-6791; Fax: +55(12) 3208-7129 - E-mail: fernando.martins@inpe.br

3 Instituto de Controle do Espaço Aéreo - ICEA, Subdiretoria de Pesquisa, Praça Mal. Eduardo Gomes, 50, Vila das Acácias, 12.228-903 São José dos Campos, SP, Brazil. Phone: +55(12) 3945-9292; Fax: +55(12) 3941-7056 - E-mail: robertotadeu@icea.gov.br

${ }^{4}$ Secretaria de Educação, Diretoria de Ensino da Região de Taubaté, E.E. Professor Mario Cardoso Franco, Rua Embaixador José Carlos de Macedo Soares, 745, Chácara Santa Luzia, 12091-400 Taubaté, SP, Brazil. Phone: +55(12) 3632-7957 - E-mail: ma_geografia@yahoo.com.br.

5 Instituto de Aeronáutica e Espaço - IAE, Divisão de Ciências Atmosféricas - ACA, Praça Mal. Eduardo Gomes, 50, Vila das Acácias, 12228-904 São José dos Campos, SP, Brazil. Phone: +55(12) 3947-4878; Fax: +55(12) 3947-4551 - E-mails: marcosmlap@iae.cta.br; cleber.voy@gmail.com
} 


\section{INTRODUCTION}

The main characteristic of the Earth seen from space is its cloud cover which varies in both time and space and can reach approximately $50 \%$ of the total area of the planet based on findings from orbital platforms (Salby, 1995).

A very significant cloud cover surrounds almost permanently the Earth. Therefore, clouds are a highly relevant atmospheric component in the processes of absorption and scattering of solar irradiance. Clouds modify the radiant energy of the sun in the atmosphere, interacting with the solar irradiance in the visible region of the electromagnetic spectrum by reflection and with the radiation emitted by the surface of the Earth and the atmosphere in the infrared region, through retention-absorption. The reflectionabsorption set is called cloud forcing (Paltridge \& Platt, 1976; Wiscombe, 1980; Salby, 1995; Echer et al., 2001; Souza Echer et al., 2004, 2005, 2006). Clouds constitute a first order effect on the modulation of solar irradiance reaching the Earth surface (Souza Echer et al., 2006; Martins et al., 2008; Silva, 2010).

Cloud cover observation is performed visually by observers on the ground, as routine operation at airports and meteorological stations of the national meteorological network. Several research works have been undertaken in order to develop a methodology to monitor automatically the cloud cover. Santos (1957), Holle \& Mackay (1975), Feister et al. (2000), Souza Echer (2004), Cazorla et al. (2008), Heinle et al. (2010) persistently sought information in images of the entire sky, which were acquired by semi-automatic and automatic systems that use digital cameras coupled with wide-angle lenses of all-sky type and, in the past, with photographic plates.

The mapping of the clouds can also be accomplished through spatial/temporal analysis of meteorological satellites (Pinker \& Laszlo, 1992; Ceballos \& Bottino, 2000; Martins et al., 2003). The current methods using satellite images can be grouped as: a) methods that establish threshold values to classify image pixels of one or more spectral channels observed by meteorological satellite; and, b) techniques and methods that analyze the statistical properties of visible and/or infrared radiance in pixel groups or image parts.

Cloud cover can also be assessed by using the solar irradiance ground data measurements to determine the $K t$ and $K d$ indices. $K t$ index is the ratio between global solar irradiance (sum of the components of diffuse and direct solar irradiance) incident on the earth's surface $(H)$ and solar irradiance that reaches the top of the atmosphere $(\mathrm{Ho}) . \mathrm{Kd}$ index is given by the ratio between diffuse solar irradiance on the ground $(H d)$ and $H o$. The relationship between $K d$ and $K t$ may be an indicator of cloud cover at the time of the measurements (lqbal, 1983).
From the efforts of several research groups to determine the fraction of cloud cover on the surface it is possible to realize the importance of such information. This study aims at verifying whether the different platforms of data acquisition on the ground (visual observation, all-sky type automatic observation, radiometer type sensors) have the capacity and sensitivity to observe the same atmospheric scenario regarding cloud cover. For that, we used solar irradiance measurements conducted at the SONDA (Sistema de Organização de Dados Ambientais) ground site operated by the Solar Energy Laboratory of the Universidade Federal de Santa Catarina (LABSOLAR/UFSC) in partnership with the Centro de Ciência do Sistema Terrestre of the Instituto Nacional de Pesquisas Espaciais (CCST/INPE). The station is located inside the UFSC campus, in Florianópolis. The second dataset was collected by an automated cloud cover monitoring system that operated during a specified period on the same platform of data collection at the SONDA station. The third dataset is the cloud cover data recorded by visual inspection of the sky at Hercílio Luz International Airport, located about $7700 \mathrm{~m}$ from the SONDA measuring site.

The term cloud cover in this work is considered as the amount of clouds present in the sky at a given time. Due to the influence of clouds in different ways throughout the solar spectrum, especially for the short-wave region, the whole discussion process is based on the visible region of the solar radiation spectrum.

\section{METHODOLOGY \\ Study area characteristics}

The two areas where cloud cover and solar irradiance data were acquired are located in Florianópolis, Santa Catarina state (SC). They are the Hercilio Luz International Airport (27०40'S latitude, $48^{\circ} 32^{\prime} \mathrm{W}$ longitude) and the Florianópolis SONDA site $\left(27^{\circ} 28^{\prime} \mathrm{S}\right.$ latitude, $48^{\circ} 29^{\prime} \mathrm{W}$ longitude, $15 \mathrm{~m}$ asl) located at the campus of Universidade Federal de Santa Catarina, UFSC.

The international airport borders to the north/northwest the Tavares Mangrove. To the west lies the South bay and to the northeast the Coastal Massif, a geographical barrier that may favor moisture retention in the airport area. The University area is located in the central part of the Santa Catarina Island bordering to the west, the central massif of Florianópolis, between 150 and $300 \mathrm{~m}$ altitude; to southwest, Morro da Serrinha with approximately $125 \mathrm{~m}$ altitude and, to south/southeast, the Coastal Massif with a maximum altitude of about $436 \mathrm{~m}$. The straightline distance separating the two areas is $7700 \mathrm{~m}$ and crosses the Tavares Mangrove, Saco dos Limões Bay and Morro da Carvoeira, with an altitude of about $200 \mathrm{~m}$. Figure 1 shows the two study areas, the picture on the right shows the areas in Florianópolis 


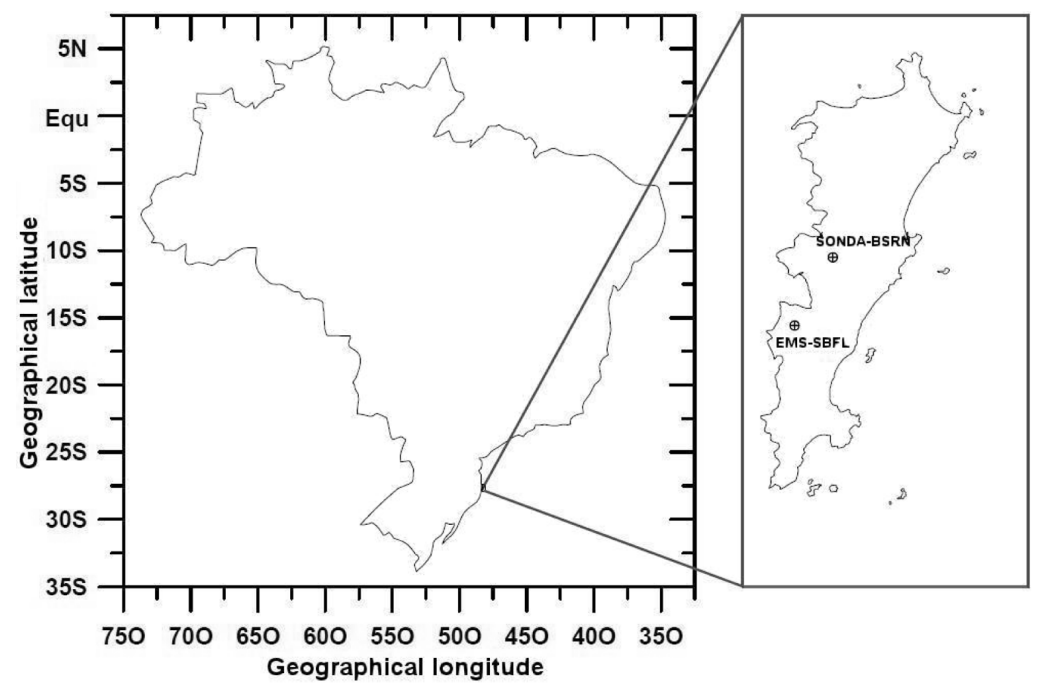

Figure 1 - Location of the areas for data collection in the Brazilian territory and on Florianópolis Island (Santa Catarina).

island while the one on the left shows the location in relation to the Brazilian territory.

The shortest distance from Santa Catarina island to the mainland is approximately $500 \mathrm{~m}$ (connected by the Hercilio Luz bridge), dividing the island's northern and southern regions. The island landscape belongs to the group of mountains of the east of Santa Catarina State, and includes several other natural landscapes such as coastal plains, cliffs, mangroves, and massive hills of granite-gneiss crystalline basement.

The climate on Santa Catarina island, according to the Köppen classification (CECCA, 1997), is humid mesothermal (Cfa) with evenly distributed rainfall, ranging from 1400 to $1800 \mathrm{~mm}$ per year. Annual average temperature ranges from $20^{\circ} \mathrm{C}$ to $22^{\circ} \mathrm{C}$ and the prevailing winds come from north (CECCA, 1997).

\section{Data Description}

\section{Visual observation cloud data}

Cloud cover observation is routinely performed by visual inspection of the sky according to the standards set by the World Meteorological Organization (WMO, 2008). The observer should be positioned where the view of the sky is completely unobstructed. The estimate should be made assuming that the existing clouds are distributed in a single continuous layer. The partial or total amount of clouds is expressed by a fraction proportional to the covered up area, with approximation to eighths and tenths. The sky is reported as completely cloudy in the presence of dense fog. When the sun and the stars can be seen clearly, and there are no clouds, it is reported as clear sky. From the description above, it is clear that visual ground observation is quite subjective, although widely accepted.
In this study, visual cloud observations were recorded every hour throughout the day, for several solar zenith angle scenarios (SZA). The amount, type and height of clouds were recorded in the appropriate forms used by the surface meteorological station of Florianópolis airport (EMS-FL), during 2002. However, in this study only the records from 06:00 UTC to 17:00 UTC (Coordinated Universal Time) period were used to ensure the best natural lighting.

According to type, the clouds can be classified based on the estimated base height, such as: stratus, stratocumulus, cumulus, cumulunimbus (low clouds); nimbustratus, altostratus, altocumulus (medium clouds); cirrus, cirrucumulos and cirrustratus (high clouds). The quantities of each type are recorded in eighths and base heights in dekameters (WMO, 2008).

For the analysis, we selected the time records of clear sky (total absence of clouds) and completely overcast sky, when the entire sky (8/8) is covered with only one type of cloud. Thus, a total of nine days of visual observation data were used, totaling 25 visual cloud observations at different times throughout the day. Five (5) days with low cloud cover and four (4) days with overcast sky at various times of the day. The kind of cloud observed in overcast sky records was stratocumulus, with base height ranging between $\approx 900$ and $1200 \mathrm{~m}$.

\section{Solar irradiance data}

Direct, diffuse and global solar irradiance data were measured at the SONDA station in Florianópolis. The collected data underwent a quality control program established by the CCST/INPE based on the criteria defined by WMO for the Baseline Surface Radiation 
Network (BSRN). The Florianópolis station was integrated to the international BSRN, in order to meet the quality standards required for the acquisition and quality control procedures of the available data. The station is equipped with the following equipment: CM21 pyranometer (Kipp \& Zonen) to measure global solar irradiance, CM22 pyranometer (Kipp \& Zonen) with a shadow sphere and a 2AP (Kipp \& Zonen) solar tracker to measure diffuse radiation. The station also has a system to acquire meteorological data such as air temperature, relative humidity, atmospheric pressure, rainfall and wind speed and direction as well. Further details about the station with photos and qualified data access can be found on the website (http://sonda.ccst.inpe.br/). A complete description of data qualification procedure is presented by Chagas et al. (2006).

The collected and qualified data are available on a one minute time basis. For this work, data were integrated into 15-minute periods, the same time period of the images collected with the all-sky system. The choice of this particular time interval was based on the work of Souza Echer (2004). The result of this procedure keeps the average values of solar irradiance and cloudy conditions during the day equated.

The pyranometers used to measure solar irradiance are arranged so they measure the incident solar irradiance through a horizontal surface, in such a way that the incident irradiance is that coming from the sun and sky over the entire elevation range from horizon to horizon, on a $360^{\circ}$ azimuth range over the zenith vector.

\section{Automatic cloud observation data}

Cloud cover data were obtained using the automatic mapping system of the cloud cover fraction based on all-sky image acquired on the ground with a camera Charge Coupled Device (CCD) type (Souza Echer, 2004). The system installed and operated on the solar data collection platform at the SONDA station provided pictures in the Joint Photographic Experts Group (JPEG) format and RGB (red, green and blue) color system, with 640x640 resolution, taken during the day between 8:45 and 21:45 (GMT). The trail of the CCD sensor was permanently damaged while adjusting the shading rod due to direct camera exposure to sunlight, which is verified by the pink line seen in Figures 5, 6, 7, 9 and 10. The damaged image area compared to the number of good quality pixels in the image does not seem to influence significantly image processing and, consequently, the response to cloud cover (Souza Echer, 2004). Clouds are dynamic systems, even if a part of this system is pictured in a presumably damaged image, the analysis of these images over time will display the total pixels covered with clouds in the observed time interval.
Subsequently, the algorithm developed by Souza (1999) was applied to analyze the images and determine cloud cover. The algorithm input are the RGB images, which are subsequently transformed into the IHS (Intensity, Hue and Saturation) color attribute space and the information contained in the saturation color allows to identify whether the pixels correspond or not to cloud sky. The main feature of this methodology is based on the difference between the saturation levels of clear skies and clouds. The colors with high saturation are said to be pure, such as clear sky. Colors with low saturation (much gray) are pastel colors, such as clouds.

\section{Theoretical development}

Clouds are extremely important for the planet climate since they play an important role as modulator of the incident solar irradiance, the so called global irradiance. The global irradiance on a horizontal surface on Earth has a direct and a diffuse component. The first corresponds to the photons that originated directly from the solar beam while the second, to the photons that have undergone multiple scattering in the atmosphere and are redirected to the surface. Since clouds are solar irradiance modulating agents, when the sky is clear direct, diffuse and global irradiance should behave similarly to Figure 2 (profiles blue, red and black, respectively). Figure 2 shows the ideal behavior of three types of incident irradiance based on data collected during August 2002 in Florianópolis region, according to UTC and SZA (lower and upper $x$ axis, respectively). Basically, Figure 2 shows that incident global irradiance behaves symmetrically, very close to a Gaussian distribution peaking at approximately 12:00 local time (or 15:00 UTC) and is, therefore, proportional to the zenith angle. The diffuse and direct irradiances are asymmetric and, such asymmetry may be associated with local surface conditions, for example, during the morning the diffuse component is greater compared to the afternoon for the same zenith angle, due to the presence of fog in the morning and assuming that it dissipates throughout the day. The same relationship, but inverse, can be attributed to the behavior of direct irradiance under clear sky condition.

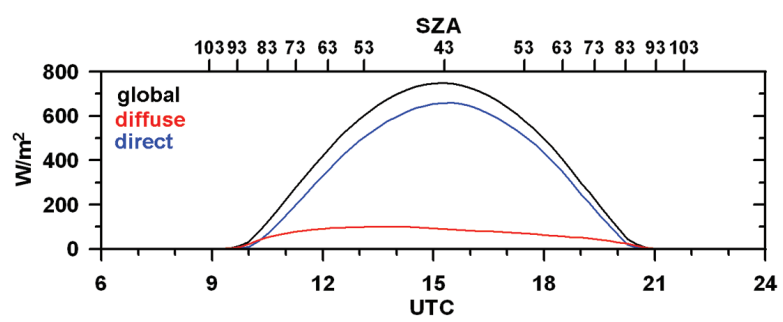

Figure 2 - Ideal profiles for direct, diffuse and global irradiance (black, red and blue curves, respectively) based on data collected during August, 2002, versus UTC and SZA (lower and upper $x$-axis, respectively). 
Figure 3 shows the relationship between diffuse and global irradiances incident on the earth's surface (quantified by $K t$ and $K d$ indices, respectively) for different cloud cover conditions. Based on the total cloud coverage $(K d=K t=0)$ and ending up with completely clear sky ( $K t \approx 0.84$ and $K d \approx 0.17$ ) (IQBAL, 1983). In order to better interpret, this figure was divided into three intervals defined as completely cloudy region $(0.0 \leq$ $K t<0.3)$, partially cloudy region $(0.3 \leq K t<0.7)$ and clear sky region $(0.7 \leq K t)$. In the first interval, the sky is supposedly covered uniformly with clouds and displays practically linear growth between $K d$ and $K t$ indices. In the second interval, the sky is partially covered while the small fluctuation of $K d$ values indicates that between 20 and $30 \%$ of the solar irradiance incident on the top of the atmosphere is transmitted to the surface and reflected, thus constituting the diffuse irradiance component. The last interval shows the index values for clear sky conditions when only the molecular scattering is responsible for the scattering of solar radiation. Accordingly, the diffuse component responds for $20 \%$ of the total solar radiation at the top of the atmosphere.

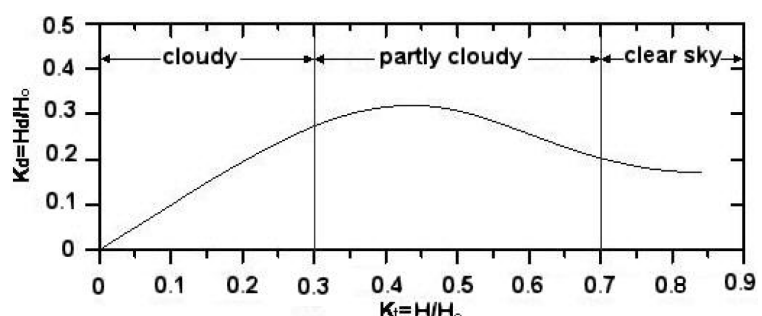

Figure 3 - Variation of diffuse irradiance $K d$ versus atmospheric transparency $K t$. Modified from IQBAL (1983), p. 253.

The cloudiness index, $K n$, defined as the ratio between $K d$ and $K t$ indices, shows the participation of the diffuse irradiance on the total solar irradiance incident on the surface. $K n$ is close to one (1) for a completely overcast sky and clouds are so thick that there is no transmission of solar direct beam by the atmosphere.

For clear skies (no clouds) the participation of the diffuse component is due to scattering of radiation by atmospheric gases (Rayleigh scattering) and aerosols (Mie scattering). The cloudiness index is expected to be between 0.2 and 0.3 .

\section{DISCUSSION}

In this study we sought to determine whether the cloud cover observations made by observers on the surface at the EMS-FL are consistent with the solar irradiance data measured at the SONDA station. For this purpose, the $K n$ index values and cloud cover visual records were compared.
Table 1 shows the year, month, day, UTC time and $K n$ indices for the visual observations recorded in periods of clear sky conditions at the airport observation station (EMS-FL). The $K n$ index values were calculated using the data from the pyranometers located at the SONDA station for 15 minute intervals before and after the visual observation at the EMS-FL.

Table 1 - Response of clear sky visual observation taken at the airport versus $K n$ index.

\begin{tabular}{|c|c|c|c|c|}
\hline Year & Month & Day & $\begin{array}{c}\text { Hour } \\
(\text { UTC })\end{array}$ & $K n^{*}$ \\
\hline 2002 & 4 & 12 & $12: 00$ & 0.91 \\
2002 & 8 & 11 & $18: 00$ & 0.11 \\
2002 & 8 & 11 & $19: 00$ & 0.16 \\
2002 & 8 & 11 & $20: 00$ & 0.26 \\
2002 & 8 & 12 & $17: 00$ & 0.22 \\
2002 & 8 & 12 & $18: 00$ & 0.23 \\
2002 & 8 & 12 & $19: 00$ & 0.30 \\
2002 & 8 & 12 & $20: 00$ & 0.47 \\
2002 & 8 & 23 & $12: 00$ & 0.16 \\
2002 & 8 & 23 & $13: 00$ & 0.13 \\
2002 & 8 & 25 & $13: 00$ & 0.17 \\
2002 & 8 & 25 & $14: 00$ & 0.15 \\
2002 & 8 & 25 & $15: 00$ & 0.13 \\
2002 & 8 & 25 & $16: 00$ & 0.13 \\
2002 & 8 & 25 & $17: 00$ & 0.14 \\
2002 & 8 & 25 & $18: 00$ & 0.16 \\
2002 & 8 & 25 & $19: 00$ & 0.20 \\
2002 & 8 & 25 & $20: 00$ & 0.30 \\
\hline \multicolumn{5}{|c}{$* n=K d / K t}$. \\
\hline
\end{tabular}

It is important to highlight that the $K n$ index for clear skies is expected to behave according to Figure $4($ a) varying from $\approx 0.1$ to $\approx 0.5$. These oscillations are associated with the SZA and seasonality of the observation site. However, such variability depending on the local time may be regarded as deterministic or almost deterministic (as the solid line shown in Fig. 4a). During dawn and dusk, the solar radiation is transmitted through a greater atmospheric mass and, therefore, it will undergo greater scattering and absorption during its transmittance in the atmosphere (higher $K n$ values). The inverse occurs close to noon (local time), where lower $K d$ values are observed (and higher $K n$ ).

Figure 4(b) shows the relative variability of $K n(\Delta K n)$ taking into account the behavior throughout the day, that is, the $K n$ values minus its estimate (as shown by the solid line in a). It is observed that $\Delta K n$ for clear sky is well described by the function used as base since its values fluctuate around zero. The variability from the base value is not higher than $10 \%$ and the 
standard deviation is $\approx 0.09$ from the mean $(\approx 0)$. This result compared to Table 1 shows that the diffuse solar irradiance component is in good agreement with the observation records for clear sky.

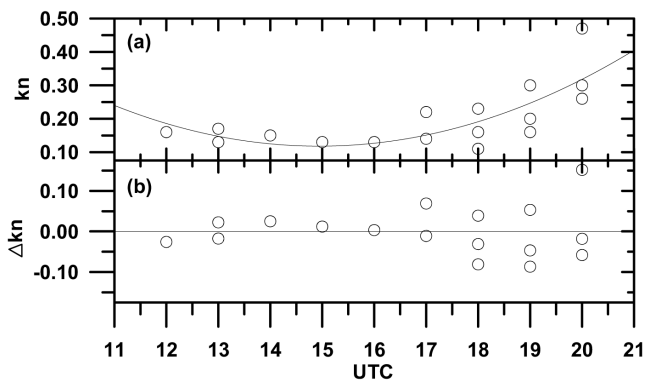

Figure 4 - (A) Kn versus time (UTC) and (B) Kn variation for clear sky.

Table 2 shows from left to right, UTC time, visibility on the airport runaway, weather, total clouds (TC), relative humidity $(\mathrm{RH})$ and, layer 1 and 2 of clouds for April 12, 2002. For this day, the data from the automated system provided information only for the afternoon, after 17:00 UTC, for the following times 17:45 UTC, 18:00 UTC, 18:15 UTC, 21:00 UTC and 21:15 UTC (see the caption of the images at the bottom of Fig. 5). The incident radiation records cover the whole day (upper panel of Fig. 5). It is seen that at 12:00 UTC on April 12, 2002, approximately 09:00 local time, the calculated $K n$ value (Table 1) does not represent the clear sky recorded at EMS-FL. This difference may be associated with the presence of mist humid early in the day over the solarimetric station at the UFSC. The relative humidity value recorded that morning at the SONDA station was above $80 \%$ and agreed with the $85 \%$ recorded for the same time at EMS-FL as shown in Table 2, which reinforces the mist humid hypothesis, very common at this time of the year. It can also be seen that from 12:00 UTC and on, relative humidity values recorded at the airport were below $80 \%$ (Table 2) while total cloud cover increased slightly. Similar cloud cover behavior was recorded by the automated system installed at the SONDA station, as well as by the pyranometers that indicated partly cloudy sky, easily seen in the images of the lower part of Figure 5.

On August 11, 2002, the cloudiness index $(K n)$ calculated from the solarimetric data collected at SONDA station varies between 0.11 and 0.26 (Table 1), reflecting the visual cloud cover records registered by the observers at the airport, that is, clear sky. The cloud cover results from the automatic monitoring were in agreement with these records and indicated cloudiness between 23.5 and $17.3 \%$, predominantly clear sky with diurnal variation between 76.4 and $82.6 \%$ shown by the pixels (Fig. 6).

The $K n$ result for August 12 shows variation between 0.22 and 0.47 (Table 1), which also agrees with the visual observation records at the airport that varied between 20.3 and $17.6 \%$, predominantly clear sky and diurnal variation between 79.6 and $82.3 \%$ shown by the pixels (Table 2). Figure 7 shows global, diffuse and direct irradiance curves versus universal time recorded on August 12, 2002.
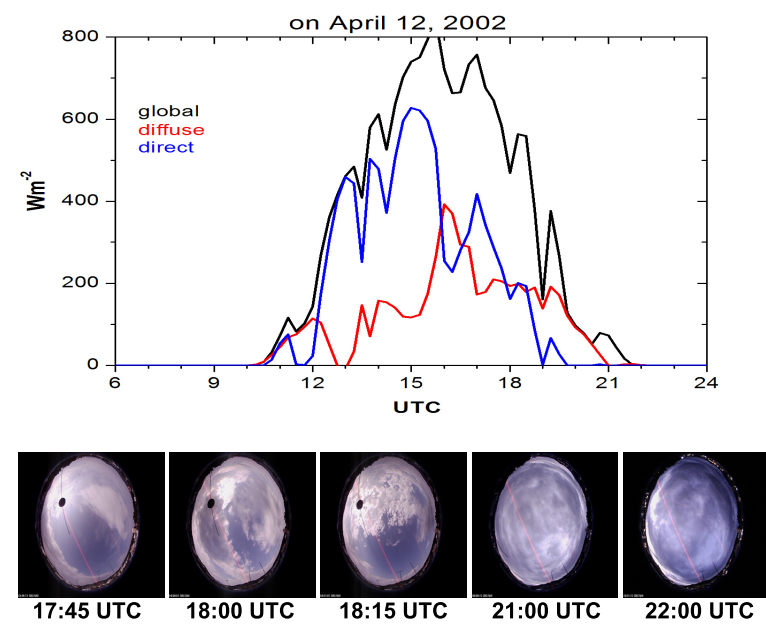

Figure 5 - Profiles for direct, diffuse and global irradiance (respectively represented by blue, red and black curves) versus universal time recorded on April 12, 2002. Lower panel shows the images recorded by the all-sky system for the same day, at five different times.

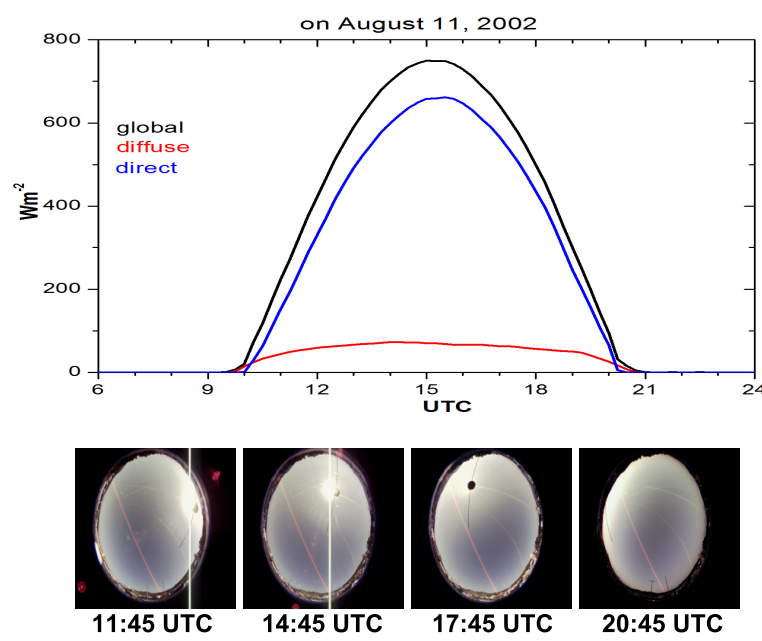

Figure 6 - Profiles for direct, diffuse and global irradiance (blue, red and black curves) versus universal time recorded on August 11, 2002 (seen in Fig. 2). Lower panel shows the images recorded by the all-sky system for the same day, at four different times.

On August 23 and 25, 2002, $K n$ values ranged between 0.16 and 0.30 , consistent with the visual observations recorded at the airport. There are no images from the automated systems for these days, only the solar radiation data (Fig. 8). Even when the sky is completely clear with no clouds, $K n$ values show that transmittance of solar irradiance in the atmosphere is not $100 \%$. 
Table 2 - Data from the airport in Florianópolis, on April 12, 2002.

\begin{tabular}{|c|c|c|c|c|c|c|}
\hline $\begin{array}{l}\text { Hour } \\
\text { (UTC) }\end{array}$ & $\begin{array}{l}\text { Visibility } \\
\text { (meters)* }\end{array}$ & Weather & TC & $\begin{array}{l}\text { UR } \\
(\%)\end{array}$ & Layer 1 & Layer 2 \\
\hline 9 & 20,000 & $x x x x$ & 5 & 97 & 2 stratocumulus & 5 cirrus \\
\hline 10 & 20,000 & $x x x x$ & 5 & 98 & 2 stratocumulus & 5 cirrus \\
\hline 11 & 7,000 & Mist & 2 & 97 & 1 stratocumulus & 2 cirrus \\
\hline 12 & 9,000 & Mist & 0 & 85 & 0 & 0 \\
\hline 13 & 9,000 & Haze & 1 & 79 & 1 stratocumulus & 0 \\
\hline 14 & 12,000 & $X X X X$ & 1 & 70 & 1 stratocumulus & 0 \\
\hline 15 & 20,000 & $X X X X$ & 4 & 67 & 1 cumulus & 4 altocumulus \\
\hline 16 & 20,000 & $x x x x$ & 4 & 68 & 1 cumulus & 3 cirrus \\
\hline 17 & 20,000 & $x x x x$ & 5 & 67 & 1 cumulus & 4 cirrus \\
\hline 18 & 20,000 & $x X X X$ & 5 & 66 & 2 cumulus & 4 cirrus \\
\hline 19 & 20,000 & $X X X X$ & 7 & 70 & 6 cumulus & 0 \\
\hline 20 & 20,000 & $X X X X$ & 7 & 74 & 6 stratocumulus & 0 \\
\hline
\end{tabular}

*Visibility is estimated visually by the observer based on visibility charts. If the estimated value is below 1,200 meters on the runway, the visibility meter equipment is used.
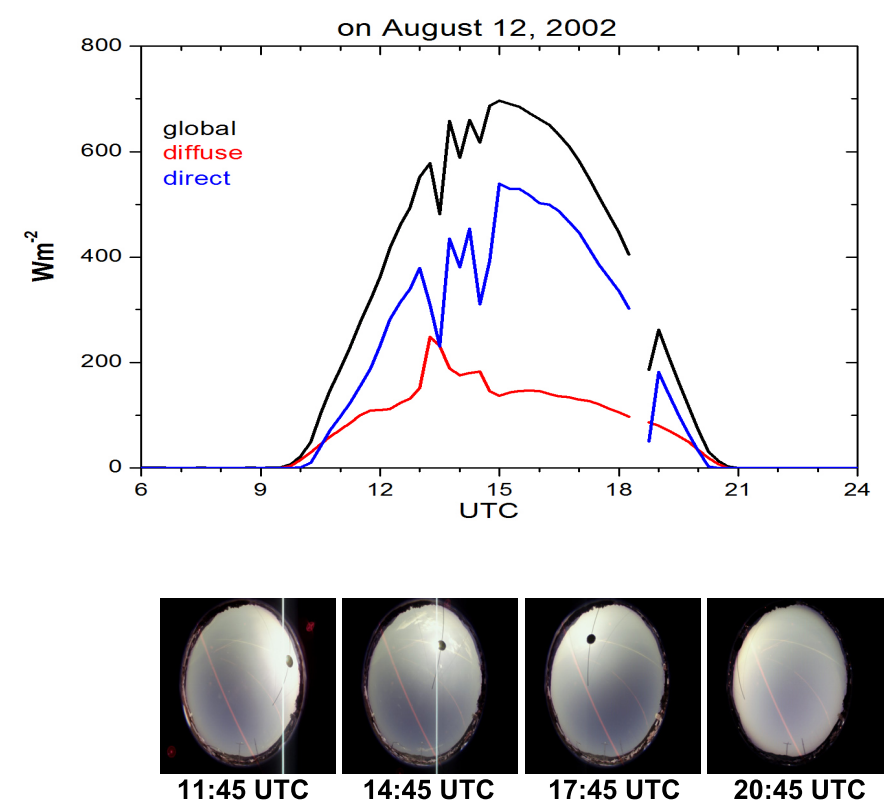

Figure 7 - Profiles for direct, diffuse and global irradiance (blue, red and black curves) versus universal time recorded on August 12, 2002. Lower panel shows the images recorded by the all-sky system for the same day, at four different times.

A scenario that has been described by IQBAL for clear sky, the molecular scattering (also known as Rayleigh) and the scattering by particles (aerosols ${ }^{1}$ ) cause the scattering of incident radiation, as seen in the third interval of the model proposed by IQBAL shown in Figure 3. Minor changes in the measurements of solar irradiance happen naturally during the day, even on clear days, since it depends on composition and dynamics of the local atmosphere at the observation areas.

It should be noted that the observers from the airport were trained to recognize clouds and to determine cloud cover from previous experience of observers on the surface. Therefore, it is expected that at the same observation areas, even with small

\footnotetext{
${ }^{1}$ Aerosols are small, solid or liquid particles found in the atmosphere. Most aerosol sources are lying on the earth surface, so aerosols are more concentrated in lower layers of troposphere, where its residence time may be days. The concentration of aerosols is related to production conditions and atmospheric transport.
} 

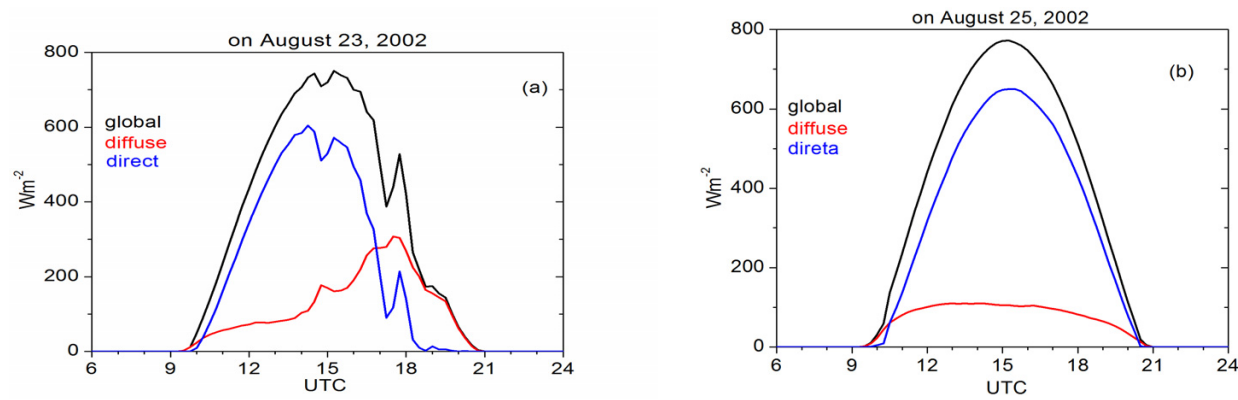

Figure 8 - Profiles for direct, diffuse and global irradiance (blue, red and black curves) versus universal time recorded on August 23, 2002 (A) and on August 25, 2002 (B).

fluctuations in the results, there will be no large discrepancies between the technician observations and the automated system regarding the final cloudiness analysis. This does not exclude the possibility of misinterpretation for both techniques used, but it minimizes the chances of undetected error.

In the studied region, the autumn was described by Souza Echer (2004) as almost always predominant good weather season, with long periods of clear days. However, there is occurrence of overcast days during the fall due to the movement of weather systems (fronts) over the region.

Table 3 has the same layout of Table 1, but shows the data regarding overcast days with one extra column on the right, showing the cloud height estimated by the technicians at the airport in Florianópolis. At these times, the observers on the surface described the sky as $100 \%$ covered by a single type of cloud, stratocumulus, at different heights (ranging from 900 to $1200 \mathrm{~m}$ ). The $K n$ indices in Table 3 show that the diffuse component has a strong participation in the global solar irradiance measured by the sensors at SONDA station.

Table 3 - Visual observation response of sky covered $100 \%$ by stratocumulus clouds obtained at the airport versus $K n$ index.

\begin{tabular}{|c|c|c|c|c|c|}
\hline Year & Month & Day & $\begin{array}{c}\text { Hour } \\
(\text { UTC })\end{array}$ & $K n^{*}$ & $\begin{array}{c}\text { Height } \\
(\mathrm{m})\end{array}$ \\
\hline 2002 & 4 & 21 & $12: 00$ & 0.90 & 1,200 \\
2002 & 4 & 21 & $13: 00$ & 0.90 & 1,200 \\
2002 & 4 & 22 & $20: 00$ & 0.91 & 900 \\
2002 & 8 & 14 & $18: 00$ & 0.86 & 1,200 \\
2002 & 8 & 14 & $19: 00$ & 0.75 & 1,200 \\
2002 & 8 & 18 & $10: 00$ & 0.86 & 900 \\
2002 & 8 & 18 & $12: 00$ & 0.98 & 900 \\
\hline
\end{tabular}

${ }^{*} K n=K d / K t$

The $K n$ indices (Table 3) did not change considerably on April 21 and 22, 2002. The values close to 0.9 are compatible with the description of completely overcast sky recorded by ground technicians at the airport. No images of cloud cover were recorded by the automated system.

In 2002, on August 14 and 18, cloudiness index measured by the pyranometers at SONDA station fluctuates between 0.86 and 0.98 (Table 3), which is in agreement with the cloudiness cover results obtained at the airport. On those days, the automated system registered between 94 and 95\% cloud cover for August 14 and between 90 and 96\% for August 16 as shown in Figures 9 and 10. The $K n$ index was expected to be close to 1 for days with almost $100 \%$ cloud cover. On August 14, it is verified that cloudiness caused all components of solar irradiance to decrease (maximum of the day $\sim 150 \mathrm{~W} / \mathrm{m}^{2}$ ). On the other hand, on August 25, (close SAZ) with clear sky both measurements at the SONDA station and airport show solar irradiance value of $750 \mathrm{~W} / \mathrm{m}^{2}$.

It is noteworthy that the automated method for determining the sky coverage, does not distinguish variations in the types of clouds, but their spatial distribution, because the algorithm lacks sensitivity to assess optical depth from the analysis of the images. Moreover, such comparative study is particularly relevant to determine the response of several methods that analyze cloudy conditions, in different scenarios at different times of the day, in order to understand the influence of geometry between position of the observer, the observed set of clouds and solar zenith angle (SZA). It is also noteworthy that the automatic system remained operative with the processed pictures following the SZA smaller than $70^{\circ}$ (Echer Souza et al., 2005).

\section{CONCLUSION}

Due to the geographical obstacles, observers at the airport do not have a direct view of the phenomena that occur at the SONDA station that is located in the center of Santa Catarina Island surrounded by massifs and hills (altitudes range from $150 \mathrm{~m}$ to $436 \mathrm{~m}$ ). This is a relevant issue regarding the use of ground data from different data acquisition platforms, even in 

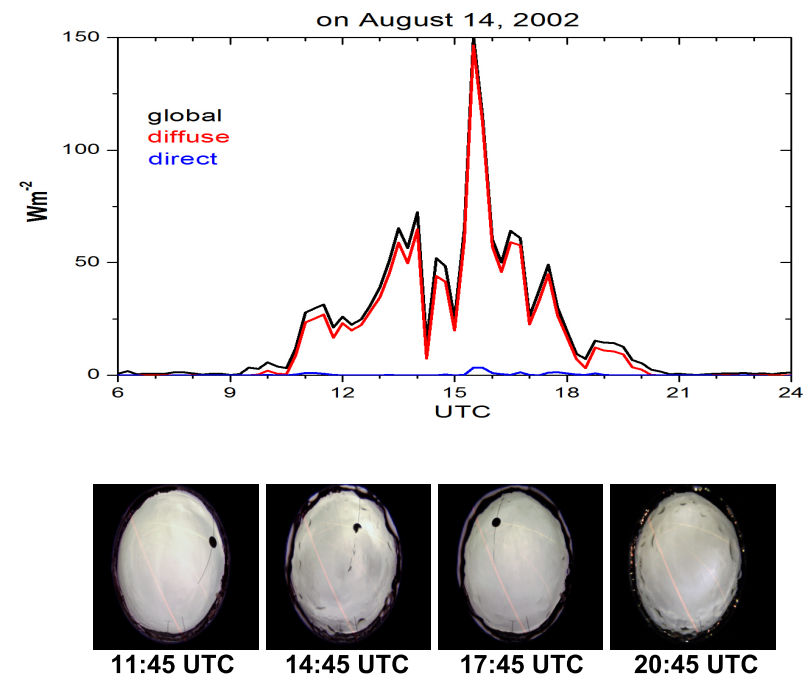

Figure 9 - Profiles for direct, diffuse and global irradiance (blue, red and black curves) versus universal time recorded on August 14, 2002. Lower panel shows the images recorded by the all-sky system for the same day, at four different times.
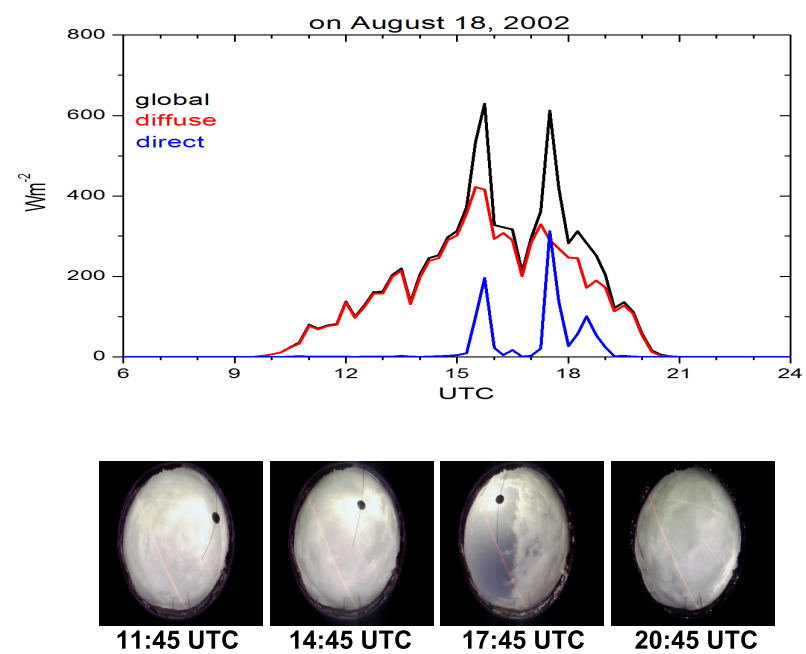

Figure 10 - Profiles for direct, diffuse and global irradiance (blue, red and black curves) versus universal time recorded on August 18, 2002. Lower panel shows the images recorded by the all-sky system for the same day, at four different times.

nearby places and when the data are reliable. In the present case study, the relief had enough significance to an understanding of the response of $K n$ index.

The $K n$ index shows the behavior of solar irradiance in the atmosphere at the study area, or, how significant the diffuse component is to the global irradiance. It is expected that this index is quite different for scenarios with $100 \%$ cloudiness compared to clear sky, since for $100 \%$ clear sky, it is expected that irradiance scattering by atmospheric gases is preferred (Rayleigh or molec- ular scattering), so global irradiance will be preferably modulated by the direct component.

It is observed that on sampled days at times of clear sky, the $K n$ index values obtained at both areas agree (distant approximately $7700 \mathrm{~m}$ from each other). However, there is one discordant day in the group shown in Table 1 (April 12, 2002) when local climate and terrain favored the different responses between the areas as evidenced by the cloud coverage images provided by the automated system (Fig. 5). On this day, relative humidity 
exceeded $80 \%$ at the SONDA station area possibly favoring mist formation and altering the optical path traversed by solar radiation to reach the radiometers.

This work shows the complexity of the interaction processes of solar irradiance with cloud cover and how it affects ground observations. The optical path when the sky is overcast was basically described by stratocumulus clouds, which are formed by globular whitish masses, often with dark patches that are sometimes separated by portions of clear skies. It can be seen that even when sky is completely ( $8 / 8$ or $100 \%$ ) covered by a single type of cloud, the ratio between global and diffuse irradiance varied between 0.98 and 0.75 , indicating the influence of this type of coverage as a function of different altitudes, spatial variations and different SZA.

Finally, the results suggest that longer time series should be used for both solar irradiance and cloudiness. Seasonality of various types of cloud cover should also be included (low, medium and high) as well as their spatial distribution on the sky in order to determine the transmittance of solar irradiance in the visible range of the solar spectrum in several cloudiness scenarios.

\section{ACKNOWLEDGMENTS}

Thanks are due to Dr. Enio Bueno Pereira (CCST/INPE) for the support and encouragement to the extremely valuable basic research for the understanding of atmospheric transmittance and availability of solarimetric data from the SONDA station. We are grateful to Dr. Sérgio Colle from the UFSC for allowing us to use the LABSOLAR for tests and install the automated system to determine cloud coverage during 2002 and 2003. We also thank Rafael Carvalho Chagas for his support and contribution to the relevant procedure of image analysis used to determine cloud coverage. Special thanks to the sub-division of aeronautical climatology of ICEA and the technicians from the Laboratório de Instrumentação Meteorológica (LIM/CPTEC) for their support operating the SONDA station. Souza Echer M.P. also thanks the PCI project 300162/2012-0 and CNPq 304368-2013-0.

\section{REFERENCES}

CAZORLA A, OLMO FJ \& ALADOS-ARBOLEDAS L. 2008. Development of a sky imager for cloud cover assessment. J. Opt. Soc. Am., 25: 29-39.

CEBALLOS JC \& BOTTINO MJ. 2000. Improved solar radiation assessment by satellite using cloud classification. In: IRS 2000: Currents problems in atmospheric radiation. A. Deepak Publishing, p. 60-63.

CHAGAS RC, MARTINS FR, PEREIRA EB, GUARNIERI RA, BONFIM JUNIOR A, NOGUEIRA JLM, de CASTRO SG, ANDRADE ES \& MANTELLI
NETO SL. 2006. Procedimentos de Validação de Dados de Radiação Solar da Rede SONDA. In: XIV Congresso Brasileiro de Meteorologia, Florianópolis. SBMET. CD-ROM.

CENTRO DE CULTURA E CIDADANIA (CECCA). 1997. Uma cidade numa ilha. 2 ed. Florianópolis: Insular, 248 pp.

ECHER E, SOUZA MP \& SCHUCH NJ. 2001. A Lei de Beer aplicada na atmosfera terrestre. Rev. Bras. de Ensino de Física, 23: 276-283.

FEISTER U, SHIELDS J, KARR M, JOHNSON R, DEHNE K \& WOLDT M. 2000. Ground-Based Cloud Images and Sky Radiances in the Visible and Near Infrared Region from Whole Sky Imager Measurements. In: Proceedings Climate Monitoring - Satellite Application Facility Training Workshop, DWD, EUMETSAT and WMO. Available on: <http://www-mpl.ucsd.edu/people//shields/publications/publications.htm> Access on: Nov 20, 2011.

HEINLE A, MACKE A \& SRIVASTAV A. 2010. Automatic cloud classification of whole sky images. Atmos. Meas. Tech. Discuss, 3: 269-299.

HOLLE RL \& MacKAY S. 1975. Tropical Claudiness from All-Sky Cameras on Barbados and Adjacent Atlantic Ocean. J. Appl. Meteor., 14: 1437-1450.

IQBAL M. 1983. Introduction to Solar radiation. London: Academic. $381 \mathrm{pp}$.

MARTINS FR, SOUZA MP \& PEREIRA EB. 2003. Comparative study of satellite and ground techniques for cloud cover determination. Adv. Spac. Res., 32/11: 2275-2280.

MARTINS FR, PEREIRA EB, SILVA SAB, ABREU SL \& COLLE S. 2008 Solar energy scenarios in Brazil. Part one: Resource Assessment. Energy Policy, 36: 2843-2854.

PALTRIDGE GW \& PLATT CMR. 1976. Radiative processes in meteorology and climatology. Amsterdam: Elsevier Scientific. 318 pp.

PINKER RT \& LASZLO I. 1992. Modeling surface solar irradiance for satellite applications on a global scale. J. Appl. Meteor., 31: 194-211.

SALBY ML. 1995. Fundamentals of Atmospheric Physics. USA: New York, $624 \mathrm{pp}$.

SANTOS JM. 1957. Contribuição aos estudos de albedo. 47 pp. Doctorate thesis (Agrometeorology) - Escola Superior de Agricultura Luiz de Queiroz, Piracicaba. (Comunicação pessoal).

SILVA AA. 2010. Taxa de dose eritematosa sob céu encoberto por altoestrato: estudo de caso. Revista Brasileira de Geofísica, 28(3): 349-355.

SOUZA MP. 1999. Desenvolvimento de uma Nova Metodologia para Determinaçã̃o de Cobertura de Nuvens. MSc. Thesis in Spacial Geophysics. São José dos Campos, Brazil. (INPE-8144-TDI 753). 108 pp.

SOUZA ECHER MP, PEREIRA EB, MANTELLI NETO SL, PEREIRA T, SOUZA RVG \& COLLE S. 2005. Desenvolvimento de um Sistema de Superfície para Mapeamento Automático da Fração de Cobertura de Nuvens. Revista de Física Aplicada e Instrumentação, 18: 10-18. 
SOUZA-ECHER MP, PEREIRA EB, BINS LS \& ANDRADE MAR. 2006. Simple Method for the Assessment of the Cloud Cover State in High Latitude Regions by a Ground Based Digital Camera. J. Atmos. Oceanic Tech., 23: 437-447.

SOUZA-ECHER MP. 2004. Development of the automatic system to assessment cloud cover fraction. São José dos Campos, Brazil: INPE.
(Ph.D. Thesis INPE-12562-TDI/1003). 187 pp.

WISCOMBE WJ. 1980. Improved Mie scattering algorithms. Appl. Opt., 19: 1505-1509.

WMO (WORLD METEOROLOGICAL ORGANIZATION). 2008. Guide to meteorological instruments and observations. WM0, no.8, 7 ed. 681 pp.

Recebido em 8 agosto, 2011 / Aceito em 8 maio, 2012

Received on August 8, 2011 / Accepted on May 8, 2012

\section{NOTES ABOUT THE AUTHORS}

Mariza Pereira de Souza Echer has a doctoral degree in Spatial Geophysics (GES/INPE). Has experience in Geosciences with emphasis in Geophysics, acting on the following subjects: physics of the atmosphere (Sun - climate binomial), digital image processing, instrumentation (geophysics), mathematical analysis of geophysical data.

Fernando Ramos Martins has a BS in Physics from the USP (1986), Masters in Nuclear Technology from IPEN (1992) and doctor degree in Spatial Geophysics from INPE (2001). Currently works as a researcher at the Centro de Ciência do Sistema Terrestre (CCST) of the Instituto Nacional de Pesquisas Espaciais (INPE). In recent years, has participated in research projects developed in collaboration with national and international research centers such the SWERA project (http://swera.unep.net/swera/) and the SONDA project (www.ccst.inpe.br/sonda). The research activities have focused on the following areas: remote sensing, geographic information systems, atmospheric modeling and survey of renewable energy resources.

Roberto Tadeu de Araujo holds a BS from the Universidade Federal de Santa Catarina (2000), technician in Aeronautical Meteorology from the Escola de Especialistas de Aeronáutica (1989). Currently, has participated in research projects developed at the Instituto de Controle do Espaço Aéreo (ICEA) and developed research in the following areas: meteorology, aeronautical meteorology, climatology, aeronautical climatology, remote sensing of the atmosphere. Has professional experience in weather observation, climatology and database.

Marcela de Ávila Villaron has a BS in Geography from the Universidade de Taubaté (2008) technician in Aeronautical Meteorology from the Escola de Especialistas de Aeronáutica (2004), specialist in assessment of fauna and flora in environmental studies from the Universidade Federal de Lavras (2010) and Masters in Environmental Sciences from the Universidade de Taubaté (2012). From 2004 to 2011, worked at the Instituto de Controle do Espaço Aéreo (ICEA), in Meteorology and Climatology projects. Has professional experience in climatology, database, and environmental analysis with emphasis on climate, teaches geography at the Secretaria Estadual de Educação de São Paulo.

Marcos Luiz de Andrade Pinto has a master degree in Remote Sensing (2001) from the Instituto Nacional de Pesquisas Espaciais (INPE). He is member of the research group in Aerospatial Meteorology of the Divisão de Ciências Atmosféricas (ACA), from the Instituto de Aeronáutica e Espaço (IAE). Has experience in Geosciences, with emphasis in Climatology and Remote Sensing, mainly in the following areas: aeronautical climatology and remote sensing of the atmosphere.

Cleber Souza Corrêa has a doctor degree in Water Resources and Environmental Sanitation (2005) from the Instituto de Pesquisas Hidráulicas, of the Universidade Federal do Rio Grande do Sul. Is a member of the research group in Aerospace Meteorology of the Divisão de Ciências Atmosféricas (ACA), of the Instituto de Aeronáutica e Espaço (IAE). Has experience in the area of Geosciences, with emphasis in Meteorology, mainly on the following topics: micrometeorology, mesoscale meteorology, climatology, numerical modeling and statistics. 